\title{
ALTERING THE GROWTH PATTERN OF KIKUYU PASTURES WITH TEMPERATE GRASSES
}

\section{K. BETTERIDGE and D.A. HAYNES 1 \\ Grasslands Division, DSIR.}

Palmerston North and 'Kaikohe.

Abstract

Temperate grasses were introduced into kikuyu-based dairy pastures to improve poor winter and spring growth rates. Methods of suppressing resident pasture growth before sowng included, forage harvesting, hard grazıng and paraquat spraying $(0.44 \mathrm{~kg}$ al/ha). Seed was either broadcast sown or direct drilled. 'Grasslands' cultivars Tama and Nui ryegrass and Matua prairie grass were used. Tiller densities, dry matter production and pasture composition were measured at 3 to 8 week Intervals in three trials ranging from 8 to 24 months duration.

Hard grazing or forage harvesting did not differentially affect subsequent pasture production Establishment of Tama was best after paraquat spraying and then direct drilling. Spring dally growth rates rose from $25 \mathrm{~kg} D M /$ ha in kikuyu pasture to $56 \mathrm{~kg} \mathrm{DM} / \mathrm{ha}$ in pasture direct drilled with Tama after paraquat spraying. but pasture growth rates were similar in early summer once Tama died. Early autumn sowing of Tama is likely to give poor establishment if kikuyu is not severely suppressed, and late autumn sowing will contribute little to winter production. In another trial Matua increased annual production through better autumn, winter and spring growth. Nui and Tama both improved growth rates in winter and spring, but only Nui increased annual production also.

Keywords: Kikuyu, Nui, Matua, Tama, establishment, paraquat, herbage production, direct drilling.

\section{INTRODUCTION}

Kikuyu (Pennisetum clandestinum) is an important pasture component in Northland (Percival 1978) and, where present, dominates other species unless rigorously controlled by hard grazing, mechanical harvesting or herbicides. Kikuyu grows most rapidly in summer and autumn but only slowly during the cool season (Lambert et al. 1979). This growth cycle of kikuyu-dominated pastures does not match the feed demand of traditional spring-calving systems. Thus cows tend to be underfed during late pregnancy and early lactation but overfed in late lactation. To avoid this problem some farmers have tried to eradicate kikuyu, but this is both expensive and difficult. Another option is to increase the pasture's content of temperate species which grow well in the cool season.

In trials in Australia and the USA temperate species improved pasture production when introduced into pastures dominated by subtropical grasses (e.g. Murtagh 1963, 1971, Colman 1966, Utley et al. 1976). Establishment and survival of introduced species is improved by chemical suppression of resident pasture (Blackmore 1957, Campbell 1974, Cook 1980, Murtagh 1971, Stafford et al. 1978) and direct drilling rather than oversowing (Robinson and Cross 1960, Watkin and Vickery 1965). Sowing later in autumn, when temperatures are cooler, results in a better performance from sown species (Murtagh 1971, Hill et al. 1985) because of reduced competition from resident pasture.

In an attempt to increase winter and spring production of kikuyu pastures, three temperate grasses were sown in autumn by different methods in three trials on dairy farms near Kaikohe. Establishment, pasture production and botanical composition were monitored.

\section{MATERIALS AND METHODS}

Three trials were established in autumn on kikuyu-dominant dairy pastures growing 
on basaltic soils. At sowing, kikuyu comprised more than $95 \%$ of herbage mass, but ryegrass, Poa spp., white clover and flat weeds were also present.

Experimental treatments and design

Four replications:

Trial 1 (split plot design)

1. Presowing management

a) Hard grazed
b) Forage harvested

2. Spraying

a) nil

3. Sowing

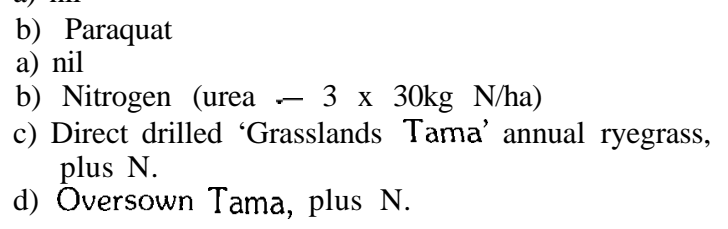

After production cuts were taken, remaining forage was grazed and plots were tyre harrowed and trimmed with a mower. Potassic superphosphate (30\%) was applied at the rate of $400 \mathrm{~kg} / \mathrm{ha}$ in both autumn and spring. The trial lasted 8 months.

Trial 2 (randomised block design)

1) Establishment method a) direct drilled into unsprayed pasture

2) Species

b) oversown into paraquat-sprayed pasture

a) nil (resident pasture)

b) Tama sown in April each year

c) 'Grasslands Nui' perennial ryegrass sown in April of year 1

d) 'Grasslands Matua' prairie grass sown in April of year 1.

Forage was cut and removed. Fertiliser N, P, K and Mg was applied following each cut at a rate to approximately replace minerals removed in herbage or lost through normal soil processes.

Trial 3

1) Time of sowing a) Nil (resident pasture)

b) Tama direct drilled in late March

c) Tama direct drilled in mid April

d) Tama direct drilled in early May

Resident pasture was forage harvested in late March only. To stimulate Tama seedlings $50 \mathrm{~kg}$ urea/ha was applied to a), b) and c) in May and to d) in July. Following production cuts, surplus forage was grazed, pastures harrowed with tyre harrows and trimmed with a mower.

Presowing management

Pasture was either hard grazed with dry cattle $(3-6 \mathrm{~cm}$ stubble) or forage harvested (2-4 cm stubble), to reduce competitiveness of kikuyu and to increase the chance of sown seed reaching the ground. Before sowing, kikuyu litter was removed and dung patches harrowed. Sprayed treatments received $2.2 \mathrm{I} / \mathrm{ha}(0.44 \mathrm{~kg}$ ai $/ \mathrm{ha})$ of paraquat as a blanket spray 2-3 hours before sowing.

Sowing and fertiliser management

Seed was either oversown by hand or direct drilled with a Duncan single-disc multiseeder fitted with hoe coulters at $15 \mathrm{~cm}$ spacings. Tama annual ryegrass, Nui perennial ryegrass and Matua prairie grass were sown at 22,15 and $40 \mathrm{~kg} / \mathrm{ha}$ respectively in both sowing methods. Matua was treated with $5 \mathrm{~g}$ benomyl $/ \mathrm{kg}$ seed to combat head smut. All treatments were lightly harrowed and rolled after sowing. 


\section{Pasture measurements}

Establishment was assessed by tiller counts in four $0.1 \mathrm{~m}^{2}$ quadrats/plot. Pasture production cuts and assessments of botanical composition were made at 3 to 8 week intervals depending on seasonal growth rates.

\section{RESULTS AND DISCUSSION}

\section{Establishment and production (Trial 1)}

Despite the generally longer but more patchy stubble of hard grazed compared with forage harvested pastures, establishment of sown grasses and the production from these pastures were so similar between the trials that only the results from the forage harvested trial are presented. Tama tiller densities 7 weeks after sowing (Table 1) were 7 times greater in the sprayed-drilled treatment than in the unsprayed oversown treatment. Direct drilling without herbicide produced more tillers than oversowingwith herbicide. Tiller densities 18 weeks after sowing showed similar trends but the range was much smaller. The percentage contribution of Tama to total production reflected these tiller density differences. Total seven-month production was higher in direct drilled than in oversown, resident + nitrogen or resident pasture treatments (Table 2). Paraquat depressed growth during autumn and early winter by $30 \%$ in resident pasture but, where Tama was drilled into sprayed pasture, growth rates were $40 \%$ greater than in unsprayed resident pasture. During early spring these differences continued except that sprayed resident pasture grew faster than unsprayed resident pasture because Poa annua was released from kikuyu competition. Ryan et al. (1978) obtained similar results from blanket sprayed pasture drilled with Tama. They had virtually no growth during the five weeks following spraying and sowing but $50 \%$ more growth six months after sowing, than in the pasture sown with Tama but without blanket spraying. Their increased production was also associated with a substantially higher content of Tama in pasture which was sprayed before sowing. In early summer, resident pasture grew more quickly than sown pastures because Tama had died. Nitrogen had no overall effect on autumn-sprayed resident pasture but did increase growth rates in unsprayed resident pasture during spring and early summer. The reason for this is not clear, but possibly more available soil nitrogen was used during winter in the faster growing unsprayed treatments, thereby inducing a spring nitrogen deficit. Blackmore (1957) and Murtagh (1971) both obtained good nitrogen responses by grasses and oats respectively, sown into chemically treated pastures in autumn. Our trial did not enable us to separate out the effect of nitrogen on Tama growth, but it is probable that the effect was beneficial as the resident pastures contained little clover for nitrogen fixation and the rapid autumn growth of kikuyu would have depleted available soil nitrogen reserves.

Thus, successfully established Tama did increase winter and spring production relative to resident pasture. Paraquat spraying increased the density of and production from Tama, but this increased pasture growth rates only during spring. During winter, the gains from Tama only offset the loss of production from the resident pasture components suppressed by herbicide.

TABLE 1: Trial 1: Tiller density of Tama 7 and 18 weeks after sowing (numbers/m²)

\begin{tabular}{|c|c|c|c|c|}
\hline & \multicolumn{2}{|c|}{ No spray } & \multicolumn{2}{c|}{ Paraquat-sprayed } \\
& Drilled & Oversown & Drilled & Oversown \\
\hline 7 weeks & $1510 \mathrm{~b}$ & $340 \mathrm{~d}$ & $2600 \mathrm{a}$ & $930 \mathrm{c}$ \\
18 weeks & $4000 \mathrm{ab}$ & $1460 \mathrm{c}$ & $4900 \mathrm{a}$ & $2610 \mathrm{~b}$ \\
\hline
\end{tabular}

Means wi thi n rows with different letters are significantly different at $\left(\begin{array}{ll}P & 0.05\end{array}\right)$ (applies to all Tables) 
TABLE 2: Trial 1: Seven month production ( $\mathrm{kg}$ DM/ha) from pasture sown with Tama in April (\% Tama contribution in parentheses).

\begin{tabular}{lccccc}
\hline & Resident R esident $+\mathrm{N}$ & Drilled & Oversown & M ean \\
\hline Paraquat-sprayed & 6165 & 5980 & $7870(88)$ & $6670(76)$ & $6670 \mathrm{a}$ \\
Not sprayed & 5365 & 6550 & $7165(76)$ & $5870(62)$ & $6235 \mathrm{a}$ \\
Mean & $5765 \mathrm{~b}$ & $6265 \mathrm{~b}$ & $7525 \mathrm{a}$ & $6270 \mathrm{~b}$ & \\
\hline
\end{tabular}

\section{Annual vs perennial grasses (Trial 2)}

Averaged over the two year trial pastures established by oversowing onto paraquatsprayed pasture produced 6\% more dry matter than those established by direct drilling. This result differs from that of the same treatments in trial 1 , most probably because a higher rate of paraquat (about 4 1/ha) was inadvertently applied in this trial, resulting in a greater suppression of kikuyu in the first year.

Tama, Nui and Matua pastures grew faster than resident pasture during winter, with Nui having a growth rate of $211 \%$ relative to resident $(100 \%)$ (Table 3). Again in spring Nui (122\%) and Tama (114\%) pastures grew faster than resident pasture, while in summer Matua pasture was the only one to outproduce resident pasture. In autumn Matua pasture had a relative growth rate of $113 \%$ compared with resident pasture $(100 \%)$, while Tama and Nui pastures grew slowest. Annual average daily growth rates ranked Matua $113 \%$, Nui $109 \%$, Tama $105 \%$ and resident pasture $100 \%$.

This trial clearly shows that all three sown grasses shifted the pattern of pasture production closer toward the feed requirement pattern of spring-calving cows. The annual performance of Tama pastures was not as good as that of Matua or Nui pastures and, because the Tama system has a high annual cost, it is a less desirable option. Matua was always as good as, or better than, resident pasture in each season and, because of its high acceptibility to cattle and its high digestibility (K. Betteridge, unpublished data), it must be considered a good companion grass in kikuyu pasture.

These results may be biased in favour of the sown grasses because the mowing regime never allowed kikuyu to smother them, as might happen under grazing in a warm wet autumn. Conversely, winter and spring growth of resident pasture may have been enhanced by the removal of the kikuyu mat, which normally suppresses cool-season growth of resident grasses such as P oa spp, ryegrasses and cocksfoot. In a trial on a similar soil only $5 \mathrm{~km}$ from this trial site (Betteridge 1983), Matua overdrilled into a ryegrass white clover pasture lifted production by an average $14 \%$ over two years.

TABLE 3: Trial 2: M ean seasonal daily growth rates averaged over two years ( $\mathrm{kg} \mathrm{DM} / \mathrm{ha} / \mathrm{day}$ ) of pastures sown with Tama, Nui or M atua in 1975 and with Tama in 1976.

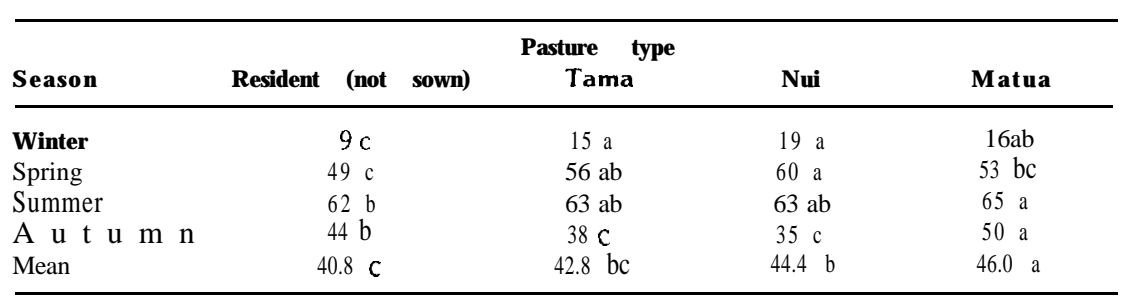

\section{Time of sowing (Trial 3)}

During March and to a less extent in April, kikuyu grew vigorously in conditions ideal for both kikuyu and establishing grasses. In both June and September, April-sown Tama had higher tiller densities than Tama sown in March or May (Table 4). Because 
TABLE 4: Trial 3: Tiller density of Tama direct drilled in March, mid April or early May 1976 (numbers $/ \mathbf{m}^{2}$ ).

\begin{tabular}{lccc}
\hline Date of count & March & $\begin{array}{c}\text { Month of sowing } \\
\text { April }\end{array}$ & May \\
\hline 30.6 .76 & $860 \mathrm{~b}$ & $1400 \mathrm{a}$ & $510 \mathrm{C}$ \\
2.9 .76 & $750 \mathrm{~b}$ & $1040 \mathrm{a}$ & $830 \mathrm{~b}$ \\
\hline
\end{tabular}

Tama was sown into kikuyu pasture which had been forage harvested but not sprayed, the April-sown result reflects the effect of decreased kikuyu competition on tillering, compared with Tama sown in March. May sowing was too late to allow for dense tillering and hence, high winter growth rates of Tama, even though there was little competition from kikuyu at that time. During the 6 months to August, April-sown pastures yielded 23\% more dry matter than resident pasture $(\mathrm{p}<0.1)$, and March and May-sown pastures yielded less. Similar results were found by Murtagh (1971) where oats, drilled into paspalum pasture, performed better when sown in May than in March. Conversely Murtagh found that when oats were sown in a cultivated seed bed highest production was obtained from March sowing due to the longer growing season. Had a herbicide been used before sowing to suppress kikuyu in our trial the March-sown Tama would probably have performed much better.

This trial highlights the strong suppressive effect kikuyu has on establishing cool season grasses whether they are newly sown or already present in the pasture.

\section{CONCLUSION}

Successfully established temperate grass species can markedly improve both annual and seasonal production from kikuyu-based pastures.

To achieve this:

the dense kikuyu mat must be removed before sowing

kikuyu should be further suppressed with herbicide, especially if seed is oversown or if drilled in early autumn

vigorous, temperate, perennial grasses such as Matua or Nui should be used in preference to annual grasses, because they eliminate the annual establishment costs associated with Tama

- the kikuyu mat must be removed each autumn by mob stocking or mechanical means to allow temperate species room to express their winter growth potential.

\section{Acknowledgments}

The technical assistance of R.K. Arneson, Grasslands Division, DSIR, Kaikohe, and statistical assistance of R.H. Fletcher, Applied Mathematics Division, DSIR, Palmerston North and Dr H R. Thompson, Applied Mathematics Division, DSIR, Wellington is gratefully acknowledged. The trials were conducted on the properties of Mr I. Brown, Ngapha, and Mr W. Smeath, Pakaraka, who are thanked for the use of their land, co-operation given and interest shown towards these trials.

\section{References}

Betteridge, K. 1983. N.2. J. exp. Agric. 11: 101-106.

Blackmore, L.W. 1957. Proc. 10th N.Z. Weed Cont Conf : 18-23

Campbell, M.H. 1974. Aust. J. Expt. Agric. Anim. Husb. 14: 507-514.

Colman, R.L. 1966. Ibid 6: 388-393.

Cook, S.J. 1980. Trop. Grasslds. 14: 181.187.

Hill, M.J.; Pearson, C.J.; Campbell, L.C. 1985. Aust, J. agric. Res. 36: 213.220.

Lambert, J.P.; Rumball P.J.; Boyd, A.F. 1979. N.Z. J exp Agric. 7: 295.302.

Murtagh, G.J. 1963. Aust. J. exp. Agric. Anim. Husb. 3: 173-176.

Murtagh, G.J. 1971. Ibid 11: 299.306

Percival, N.S. 1978. N.Z. J. exp. Agric. 6: 19.21.

Robinson, G.S.; Cross, M.W. 1960. Proc, 8th Int. Grassld Cong.: 402.

Stafford, L.T.; O'Donovan, S.F.; Raftery, T.F. 1978. Irish J. agric Res. 17: 283.294.

Utley, P.R.; Marchant, W.H.; Mc Cormack, W.C. 1976. J. Anim. Sci. 42: 16-20.

Watkin, B.R.; Vickery, P.J. 1965. Aust, J. exp. Agric. Anim. Husb. 5: 23-28. 